\title{
グロー放電質量分析法による高純度モリブデン中の 微量元素の定量
}

\author{
溝田 隆之*，中村 徹也 ${ }^{* *}$, 岩 崎 廉 ${ }^{\circledR *}$
}

(1992 年 1 月 31 日受理)

\begin{abstract}
グロー放電質量分析法により高純度モリブデン中の $\mathrm{ppb}$ ppm レベルの微量 37 元素を迅速定量し た. 約 3 時間にわたる繰り返し測定の結果から，王水で洗浄した試料について更に表面污染を除くた めに約 30 分, 特に超微量の炭素, 酸素, 塩素の定量では 2 時間の予備放電が必要なこと, 大部分の元 素についての再現性は相対標準偏差で $3 \%$ 以下であることが分かった。 又 ICP-AES など他法による 分析結果との比較ができたナトリウム, アルミニウム，鉄など 10 元素については，一方の分析結果が 他方の 2 倍を超えることがなく，ここで使用したVG 社推奨の相対感度係数が実用上満足すべきもの であることが分かった。なお，チタンはモリブデンの二価イオンの妨害のため定量困難であり，亜鉛， 銀についても何らかの妨害が予想された。
\end{abstract}

\section{1 緒言}

エレクトロニクス産業において重要な材料の一つであ るモリブデンの简純度化に伴い, その評価方法の確立が 望まれている.しかし，最も一般的な評価方法である微 量成分分析についての報告はきわめて少なく，イオン交 換分離-ICP 質量分析法によるウラン, トリウムの定 量 $^{1)}$, ヒ素, ビスマス, アンチモン，七レン，テルルの 水素化物発生-ICP 発光分光法による年量 ${ }^{2}$ など, 一部 の元素についての報告をみるにすぎない，高純度金属の 純度を正しく詊価するためには，金属元素だけでなく非 金属元素やガス成分まで, 多くの元素について, その存 在の有無や含有量を把握することが望ましい.

化学的性質の異なる多くの元素を定量する場合，試料 の分解や日的元素の分離と濃縮を必要とする方法では, 各元素あるいは元素群によってそれぞれ原理や操作が異 なり，一つの試料についてさえも，その純度を明らかに するには長時間と多大な労力を必要とする. 又試料処理 における污染についても細心の注意が要求される.

グロー放電質量分析法 (GD-MS) は，（1）非金属元 素を含むすべての元素が分析の対象となる，(2) マトリ ックスの影響が小さく, 元素閏の感度差が大部分の元素

* (財) 神奈川高度技術支援財比高度計測センター: 213 神奈川県川崎师高津区圾) ‘ 3-2-1

** (株)東芝横浜金禹部品工場品質保証部: 235 神奈川 県横浜市僟子区新杉旧町 8
について1けた以内であるため, 標準試料が得難い場 合でも半定量分析が可能である，(3) 固体試料を直接分 析に供するために，污染を受ける機会が極めて少ないな ビの長所を有し，高純度金属の分析には特にふさわしい 手段と考えられる. 最近, 高純度アルミニウム ${ }^{3) 4) や チ ~}$ 夕ン ${ }^{5)}$, 希土類金属 ${ }^{6)}$, 銅 ${ }^{7) 8)}$ について基礎及び実用的な 研究が行われている. 又, 30 種類の合金標準試料を用 いて, 元素の相対感度係数を実験的に求め, 半経験モデ ルによる考察を行い, 分析值の正確さの向上を目指した 報告9)もある.

本研究では,グロ一放電質量分析法を用いて高純度モ リブデン中の微量不純物元素を迅速に定量する目的で, 放電条件の変動が分析結果に与える影響, 試料の酸によ る洗浄後なお残る表面污染とそれを除くための予備放電 時閒, マトリックスであるモリブデンと, 放電ガスとし て使用したアルゴンに起因する妨害イオンなどの基礎的 な問題について検討した. 更に一部の元素については, 他法による分析值と比較し, GD-MS による分析結果の 正確さについて評価した。

\section{2 実験}

\section{$2 \cdot 1$ 装置及び測定方法}

使用した装置は，VG Elemental 社製 VG9000であ る. 放電セルは, タンタル製 “メガセル”と称されるも のであり, 測定中, 試料とともに液体窒素で冷却した。 グロー放電は $3 \mathrm{~mA}$ の定量流モードで行い, 電圧を 1 
$\mathrm{kV}$ に保つように放電ガス（純度 $99.9999 \%$ 以上のアル ゴン）の導入量を調節した。最大のイオンビーム強度が 得られるようにソースディファイニングスリット及びイ オンレンズ系を調整し，質量分解能 4000 以上が得られ るようにコレクターファイナルスリットを調節した．検 出器及び積分時間, 積算回数 (掃引回数) はマトリック ス元素に対しては，それぞれファラデーカップ, 160 ms, 1 回, 微量元素に対しては, それぞれデイリーマル チプライヤー, $200 \mathrm{~ms}, 1$ 回とし, 特にウランとトリウ ムに対しては, 積算回数を 50 回とした。両検出器の感 度差は, あらかじめそれぞれについて計数効率を測定し 校正した.

上記測定条件に従い，あらかじめ選定した同位体 ( $2 \cdot 3$ 及び Table 3 参照) について, マトリックス元素 モリブデンのイオン電流に対する定量元素のイオン晻流 比を測定した。次いで同位体存在比の補正を行い, 得ら れた值にその元素の相対感度係数（RSF）を乗じて濃度 值 (wt. ppm) を得た.

\section{$2 \cdot 2$ 試 料}

試料は東芝製高純度モリブデンを含む 3 種（一辺 2.3 $\mathrm{mm}$, 長さ $22 \mathrm{~mm}$ の角棒 2 種, 值径 $0.8 \mathrm{~mm}$ のワイヤー 1 種, No. 1 3), Jhonson Matthey 製モリブデン棒 1 種 (值径 $2.3 \mathrm{~mm}$, 長さ $20 \mathrm{~mm}$ の丸棒に加工, No. 4), 及 び高純度化学研究所製の純度 $99.9 \%$ 以上.と表示された モリブデン（值径 $2.0 \mathrm{~mm}$, 長さ $22 \mathrm{~mm}$ の丸棒, No. 5)である.いずれの試料も王水に 5 分程度浸して表面 を溶解後，イオン交換水で洗浄，温風乾燥を行って测走
に供した。なお，塭酸及び硝酸は和光純薬工業製有害重 金属測定用をそのまま用い，最終洗浄に用いるイオン交 換水は比抵抗 $16.5 \mathrm{M} \Omega \mathrm{cm}$ 以上のものを用いた.

\section{$2 \cdot 3$ 妨害イオンの干渉への眍慮}

モリブデンには 7 個の同位体，すなわち質量数 92, 94，95，96，97，98 及び 100 が存在しその存在率は 9.25\%〜24.13\% にわたっている. 従って, マトリック スであるモリブデン及び放電ガスアルゴンに起因する一 価及び二価の単原子イオンや多原子イオンの種類は極め て多様なものになる．これらの中で実際に定量分析にか かわるものを Table 1 にまとめた. フッ素, クロム, 鉄, テルル, バリウム, 七リウムに対して, それぞれア ルゴンの二価イオン, アルゴンと酸素とが結合した一価 イオン, モリブデンとアルゴンとが結合した一価イオン が近接するが, フッ素, クロム, 鉄については質量分解 能 4000 以上ではその影響は問題にならない. タングス テンについては, ${ }^{184} \mathrm{~W}^{+}$は ${ }^{92} \mathrm{Mo}_{2}{ }^{+}$とは完全に分離さ れる. 一方, カリウムについても, 主体となる ${ }^{39} \mathrm{~K}^{+}$が ${ }^{38} \mathrm{ArH}^{+}$と重なるが ${ }^{38} \mathrm{Ar}$ の存在率が少ない（0.063\%） ため，ほとんど問題にならない，しかし，テルル，バリ ウム, セリウムはいずれも存在率の高い同位体が妨害を 受け，高いバックグラウンドを与える．カルシウムの定 量では， ${ }^{40} \mathrm{Ca}(96.94 \%)$ と ${ }^{40} \mathrm{Ar}$ が重複するため ${ }^{44} \mathrm{Ca}(2.09 \%)$ を用いなければならない。チタンはすべ ての同位体の一価イオンがモリブデンの二価イオンに重 複し，カドミウムも存在率の高い同位体の一価イオンが すべてモリブデンと酸素とが結合した一価イオンに重複

Table 1 Interfering ions in the determination of impurities in molybdenum

\begin{tabular}{|c|c|c|c|c|c|}
\hline Isotope & Abundance, $\%$ & Interfering ion & Isotope & Abundance, \% & Interfering ion \\
\hline${ }^{\dagger 19} \mathrm{~F}$ & 100 & ${ }^{38} \mathrm{Ar}^{2+}$ & ${ }^{108} \mathrm{Pd}$ & 26.46 & ${ }^{92} \mathrm{Mo}^{16} \mathrm{O}^{+}$ \\
\hline${ }^{\dagger 39} \mathbf{K}$ & 93.25 & ${ }^{38} \mathrm{ArH}^{+}$ & ${ }^{110} \mathrm{Cd}$ & 12.49 & ${ }^{94} \mathrm{Mo}^{16} \mathrm{O}^{+}$ \\
\hline${ }^{40} \mathrm{Ca}$ & 96.94 & ${ }^{40} \mathrm{Ar}^{+}$ & ${ }^{111} \mathrm{Cd}$ & 12.80 & ${ }^{95} \mathrm{Mo}^{16} \mathrm{O}^{+}$ \\
\hline${ }^{46} \mathrm{Ti}$ & 8.0 & ${ }^{92} \mathrm{Mo}^{2+}$ & ${ }^{112} \mathrm{Cd}$ & 24.13 & ${ }^{96} \mathrm{Mo}^{16} \mathrm{O}^{+}$ \\
\hline${ }^{47} \mathrm{Ti}$ & 7.3 & ${ }^{94} \mathrm{Mo}^{2+}$ & ${ }^{113} \mathrm{Cd}$ & 12.22 & ${ }^{97} \mathrm{Mo}^{16} \mathrm{O}^{+}$ \\
\hline${ }^{48} \mathrm{Ti}$ & 73.8 & ${ }^{96} \mathrm{Mo}^{2+}$ & ${ }^{114} \mathrm{Cd}$ & 28.73 & ${ }^{98} \mathrm{Mo}^{16} \mathrm{O}^{+}$ \\
\hline${ }^{49} \mathrm{Ti}$ & 5.5 & ${ }^{98} \mathrm{Mo}^{2+}$ & ${ }^{116} \mathrm{Cd}$ & 7.49 & ${ }^{100} \mathrm{Mo}^{16} \mathrm{O}^{+}$ \\
\hline${ }^{50} \mathrm{Ti}$ & 5.4 & ${ }^{100} \mathrm{Mo}^{2+}$ & ${ }^{128} \mathrm{Te}$ & 31.69 & ${ }^{92} \mathrm{Mo}^{36} \mathrm{Ar}^{+}$ \\
\hline${ }^{\dagger 52} \mathrm{Cr}$ & 83.79 & ${ }^{36} \mathrm{Ar}^{16} \mathrm{O}^{+}$ & ${ }^{130} \mathrm{Te}$ & 33.80 & ${ }^{92} \mathrm{Mo}^{38} \mathrm{Ar}^{+}$ \\
\hline${ }^{\dagger 56} \mathrm{Fe}$ & 91.72 & ${ }^{40} \mathrm{Ar}^{16} \mathrm{O}^{+}$ & & & ${ }^{94} \mathrm{Mo}^{36} \mathrm{Ar}^{+}$ \\
\hline${ }^{74} \mathrm{Ge}$ & 36.5 & ${ }^{38} \mathrm{Ar}^{36} \mathrm{Ar}^{+}$ & ${ }^{138} \mathrm{Ba}$ & 71.70 & ${ }^{98} \mathrm{Mo}^{40} \mathrm{Ar}^{+}$ \\
\hline${ }^{78} \mathrm{Se}$ & 23.5 & ${ }^{38} \mathrm{Ar}^{40} \mathrm{Ar}^{+}$ & & & ${ }^{100} \mathrm{Mo}^{38} \mathrm{Ar}^{+}$ \\
\hline${ }^{80} \mathrm{Se}$ & 49.6 & ${ }^{40} \mathrm{Ar}^{40} \mathrm{Ar}^{+}$ & ${ }^{140} \mathrm{Ce}$ & 88.48 & ${ }^{100} \mathrm{Mo}^{40} \mathrm{Ar}^{+}$ \\
\hline${ }^{93} \mathrm{Nb}$ & 100 & ${ }^{92} \mathrm{MoH}^{+}$ & ${ }^{\dagger 184} \mathrm{~W}$ & 30.67 & ${ }^{92} \mathrm{Mo}^{92} \mathrm{Mo}^{+}$ \\
\hline
\end{tabular}

$\dagger$ No interference under resolution of 4000 or more 
する. 又，ニオブについては，唯一の同位体の一価イオ ンが ${ }^{92} \mathrm{MoH}^{+}$に重複する。従って，チ夕ンは定量困難 であり，カドミウムとニオブは試料中の酸素や水素が多 い場合，高いバックグラウンドを与える．七レンについ ては, 同位体存在量の多い ${ }^{78} \mathrm{Se}^{+}(23.5 \%)$ 及び ${ }^{80} \mathrm{Se}^{+}(49.6 \%)$ はそれぞれ ${ }^{38} \mathrm{Ar}^{40} \mathrm{Ar}^{+},{ }^{40} \mathrm{Ar}_{2}{ }^{+}$に重複す るため, ${ }^{77} \mathrm{Se}(7.6 \%)$ を用いた。

\section{3 結果及び考察}

\section{$3 \cdot 1$ 放電電圧の影響}

定量分析に先立ち，グロ一放電の電流及び電压を 3 $\mathrm{mA}, 1.0 \mathrm{kV}$ に调節するが, 測定の間, 若干の電圧変動 を認めることがあった。 そこで,この電圧変動が, 測定 する元素のイオン央流㑬及びイオン電流比によ゙の程度の 影響を与えるか, 試料 No. 4 を用いマトリックス元素 モリブデン $\left({ }^{98} \mathrm{Mo}\right)$ 及び微量成分のクロム $\left({ }^{52} \mathrm{Cr}\right)$, 夕 ングステン $\left({ }^{184} \mathrm{~W}\right)$ について調べ，結果を Fig. 1 及び Fig. 2 に示した。放電電圧を放電用アルゴン流量を調節 することにより $0.7 \sim 1.2 \mathrm{kV}$ の範囲で変化させると, 放 電電圧の増加に伴い，イオン電流值はモリブデン，クロ ム, タングステンいずれも増加するが，その傾きが元素 によって少し異なる. 従って, マトリックス元素モリブ デンとのイオン電流比は，クロムではほぼ一定であるの に対し，タングステンでは減少が恋められた。次に分析

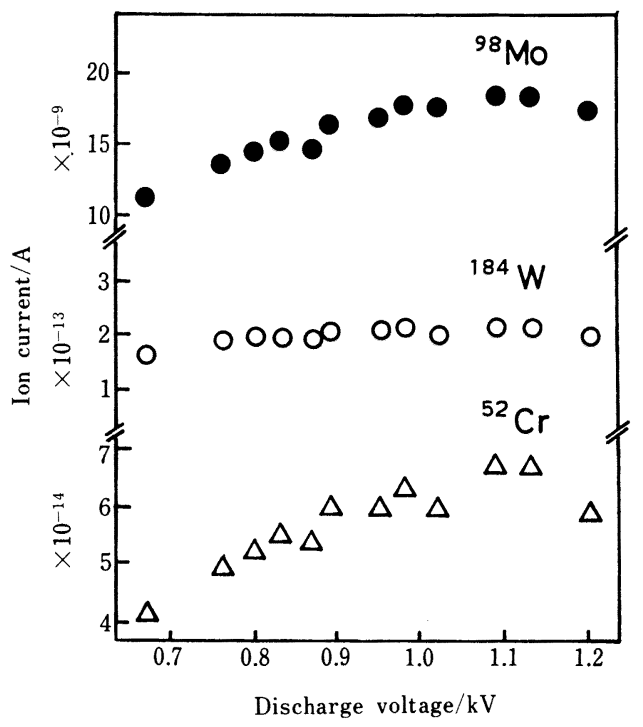

Fig. 1 Effect of discharge voltage on the ion current for trace elements ${ }^{52} \mathrm{Cr},{ }^{184} \mathrm{~W}$ and matrix element ${ }^{98} \mathrm{Mo}$
結果の正確さ及び変動を調べるために，保証値のあるマ グネシウム，クロム，鉄について放電電圧の影響を検討 した結果を Table 2 にまとめた。ここで分析值はイオ ン電流比を “推奨” RSF (後述) で補正したものを示し た. 鉄については，わずかに減少傾向が認められたが， マグネシウム，クロムについては，明りょうな増加ある いは娍少は瑟められなかった。実際に分析を行う場合，

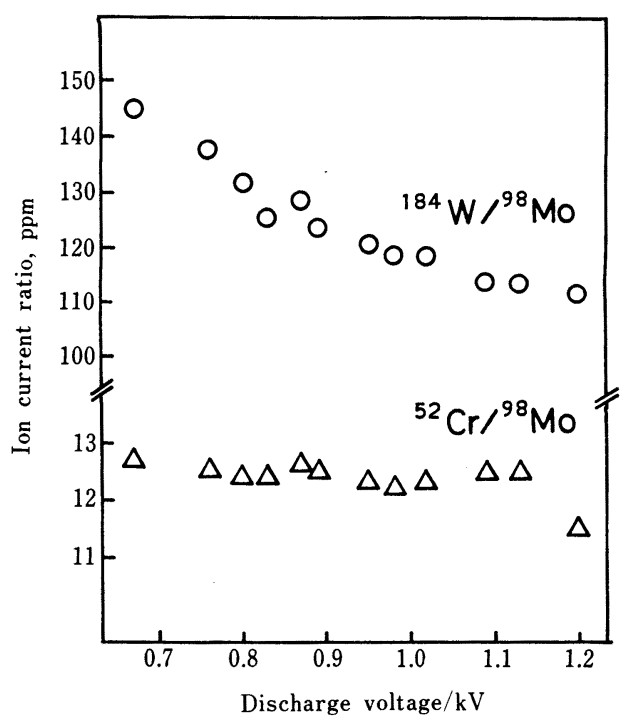

Fig. 2 Effect of discharge voltage on the ion current ratio of trace element to matrix element ${ }^{98} \mathrm{Mo}$

Table 2 Effect of discharge voltage on the analytical results for $\mathrm{Mg}, \mathrm{Cr}$ and $\mathrm{Fe}$ in molybdenum

\begin{tabular}{ccrcc}
\hline $\begin{array}{c}\text { Voltage/ } \\
\text { kV }\end{array}$ & $\begin{array}{c}\text { Order of } \\
\text { measurement }\end{array}$ & $\begin{array}{c}\mathrm{Mg}, \\
\mathrm{ppm}\end{array}$ & $\begin{array}{c}\mathrm{Cr}, \\
\mathrm{ppm}\end{array}$ & $\begin{array}{c}\mathrm{Fe}, \\
\mathrm{ppm}\end{array}$ \\
\hline 0.67 & 4 & 12.2 & 23.7 & 26.6 \\
0.76 & 5 & 10.3 & 23.1 & 25.3 \\
0.80 & 6 & 11.1 & 23.0 & 25.2 \\
0.83 & 8 & 11.0 & 23.0 & 24.2 \\
0.87 & 3 & 11.3 & 23.4 & 25.5 \\
0.89 & 9 & 9.4 & 23.1 & 23.9 \\
0.95 & 7 & 10.6 & 22.7 & 22.8 \\
0.98 & 10 & 10.1 & 22.6 & 23.1 \\
1.02 & 1 & 9.6 & 23.0 & 22.9 \\
1.09 & 12 & 9.0 & 23.1 & 22.8 \\
1.13 & 11 & 11.3 & 23.2 & 22.9 \\
1.20 & 2 & 9.3 & 21.4 & 22.6 \\
\hline
\end{tabular}

Sample : Jhonson Matthey molybdenum rod (batch No. 31825). Certified (ppm): Mg 10.5, Cr 30, Fe 25 
測定中の笔圧変動はたかだか $\pm 0.05 \mathrm{kV}$ であり，この範 井での 3 点の分析値の平均及び標準偏差は, マグネシ ウム, クロム，鉄についてそれぞれ $10.1 \pm 0.4$, $22.8 \pm 0.2,22.9 \pm 0.1 \mathrm{ppm}$ と算出され，この程度の変動 は全く問題にならないことが分かった。保証値との偏り は計算に使用した RSF に依存することから，マグネシ ウム，鉄についてはこの推奨 RSF が妥当であり，クロ ムについては再評価が必要であることが分かる。

\section{$3 \cdot 2$ スパッタリングによる表面污染の除去}

放電電圧を $1.00 \pm 0.03 \mathrm{kV}$ に保ちながら放電を続け， 試料 No. 5 を用いて放電開始後それぞれ 10 分， 50 分, 100 分, 200 分, に年量を始めたときの繰り返し再 現性を調べた。

その結果，クロム，マンガン，鉄，コバルト，ニッケ ル, 銅 (以上, 分析值 5 30 ppm), タングステン (分

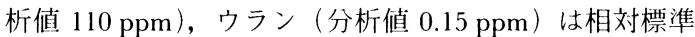
偏差 $3 \%$ 以内で極めて良い繰り返し精度が得られた が，アルミニウム，ケイ素，カリウムについては相対標 準偏差で 6〜30\% のばらつきが認められた。 アルミニ ウムについては，測定ごとに徐々に減少がみられ，ホウ 素，炭素，ナトリウム，ケイ素，硫黄，塩素について は，この試料をはじめ幾つかの試料で最初の測定值（放 電開始後 20 分以内） が污染によるとみられている高い 値を示した。
一方, 予備放殗 2 時間後, 連続 4 回（所要特間約 2 時間）の繰り返し测定精度は，ナトリウム，アルミニウ ム，ケイ素，カリウムも含め $0.2 \sim 110 \mathrm{ppm}$ にわたる多 くの元素に対し，相対標準偏差で 3\% 以内であった。

炭素, ナトリウム, 及び塩素について放電時間に伴 い，スパッタリングにより污染が除去される経過を一つ の試料について Fig. 3 にまとめた.

以上の結果を総括すると炭素, 塭素あるいは $0.1 \mathrm{ppm}$ 以下のごく微量のナトリウム, アルミニウム, ケイ素な

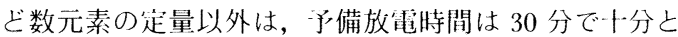
考えられた。 又 ppbレベルの炭素, 酸素, 塩素につい ては 2 時間の予備放電を必要とした。

\section{$3 \cdot 3$ 実際試料の分析結果}

モリブデンやアルゴンに起因する妨害がないと思われ る同位体を用いて得られた 37 元素についての GD-MS による分析結果を，一部の元素についての他法による結 果と合わせて Table 3 にまとめた。ここで RSF は，モ リブデン中の元素に対して実験的に測定されたものを䏔 いるのが最も正確な結果を与えるが，現在，この月的に 使用できる標準試料はない。そこでここでは，VG Elemental 社が推奨する RSF (Table 3) を用いて補正 計算を行った，炭素や酸素の分析結果を除いて GD-MS による分析結果は，他法による結果とほぼ一致し，一方 の分析結果が他方の 2 倍を超えることはなかった。こ

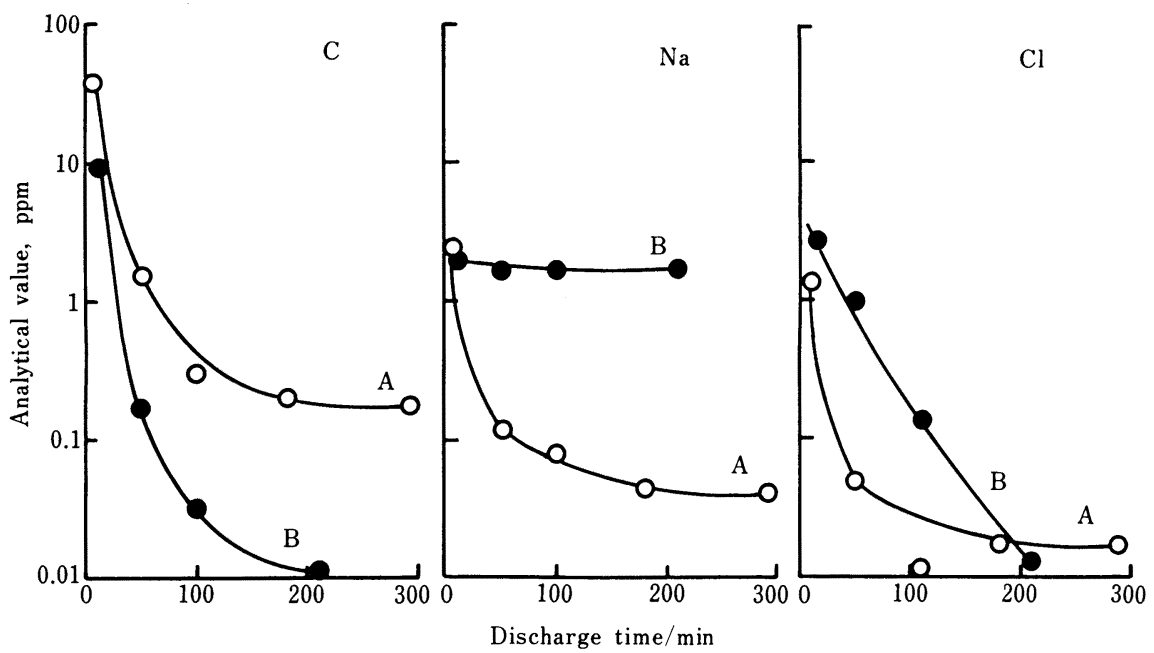

Fig. 3 Effect of preliminary discharge time on the analytical values of $\mathrm{C}, \mathrm{Na}$ and $\mathrm{Cl}$.

A: Sample No. 5, B: Sample No. 2 
Table 3 Analytical results of 37 impurities in molybdenum samples, ppm

\begin{tabular}{|c|c|c|c|c|c|c|c|}
\hline \multirow{2}{*}{ Element } & \multirow{2}{*}{$\mathrm{RSF}^{\dagger}$} & \multicolumn{2}{|c|}{ No. 1} & \multicolumn{2}{|c|}{ No. 2} & \multicolumn{2}{|c|}{ No. 3} \\
\hline & & GD-MS & Others & GD-MS & Others & GD-MS & Others \\
\hline $\mathrm{B} \quad(11)$ & 1.16 & $<0.005$ & & $<0.005$ & & $<0.005$ & \\
\hline $\mathrm{C} \quad(12)$ & 4.49 & 0.31 & $<5^{a)}$ & 0.05 & $9^{\text {a) }}$ & 3.1 & $62^{a)}$ \\
\hline$N \quad(14)$ & & 0.04 & & 0.11 & & 0.10 & \\
\hline$O \quad(16)$ & 11.8 & 3.1 & $<5^{b)}$ & 7.2 & $30^{\mathrm{b})}$ & 38 & $132^{b)}$ \\
\hline $\mathrm{Na}(23)$ & 1.81 & 0.005 & $<0.05^{c)}$ & 1.93 & $\left\langle 1^{\mathrm{c})}\right.$ & 3.68 & $2^{c)}$ \\
\hline $\operatorname{Mg}(24)$ & 1.38 & $<0.005$ & $0.001^{\mathrm{d})}$ & 1.35 & $2^{\mathrm{d})}$ & 2.56 & $2^{(1)}$ \\
\hline $\mathrm{Al}(27)$ & 1.23 & 0.009 & $0.001^{\mathrm{d})}$ & 0.20 & $1^{d)}$ & 0.52 & $2^{(1)}$ \\
\hline $\mathrm{Si} \quad(28)$ & 1.65 & 0.39 & & 6.08 & $10^{c)}$ & 187 & $\left.240^{c}\right)$ \\
\hline $\mathrm{P} \quad(31)$ & 2.82 & 0.08 & & 9.46 & & 4.78 & \\
\hline $\mathrm{S} \quad(32)$ & 3.49 & $<0.005$ & & 0.49 & & 0.19 & \\
\hline $\mathrm{Cl}(35)$ & & 0.02 & & 0.03 & & 0.05 & \\
\hline $\mathrm{K} \quad(39)$ & 1.08 & 0.05 & $\left.<0.05^{c}\right)$ & 13.4 & $11^{\mathrm{c})}$ & 250 & $99^{(-)}$ \\
\hline $\mathrm{Ca}(44)$ & 0.50 & $<0.05$ & $0.001^{\mathrm{d})}$ & 17.1 & $33^{\mathrm{d})}$ & 23.1 & $20^{\mathrm{d})}$ \\
\hline $\mathrm{V} \quad(51)$ & 0.50 & 0.047 & & 2.02 & & 1.23 & \\
\hline Cr $(52)$ & 1.98 & 0.013 & $0.004^{\mathrm{d})}$ & 13.3 & $14^{\mathrm{d})}$ & 29.6 & $24^{\mathrm{d})}$ \\
\hline $\operatorname{Mn}(55)$ & 1.30 & $<0.005$ & $<0.001^{\mathrm{d})}$ & 1.61 & $<1^{\text {d) }}$ & 2.05 & $<1^{\text {d) }}$ \\
\hline $\mathrm{Fe}(56)$ & 0.89 & 0.008 & $0.007^{\mathrm{d})}$ & 23.5 & $29^{d)}$ & 56.4 & $66^{d)}$ \\
\hline Co $(59)$ & 0.98 & $<0.005$ & & 0.33 & & 1.79 & \\
\hline $\mathrm{Ni}(60)$ & 1.35 & $<0.01$ & $0.001^{d)}$ & 26.1 & $22^{\mathrm{d})}$ & 35.8 & $53^{d)}$ \\
\hline $\mathrm{Cu}(63)$ & 4.60 & 0.045 & $0.03^{\mathrm{d})}$ & 2.6 & $2^{\text {d) }}$ & 3.0 & $3^{\text {d) }}$ \\
\hline $\mathrm{Zn}(64)$ & 5.16 & 0.05 & $0.001^{d)}$ & 1.9 & $<1^{\mathrm{d})}$ & 2.3 & $<1^{\text {d) }}$ \\
\hline $\mathrm{Ga}(71)$ & 4.08 & $<0.05$ & & 0.35 & & 0.11 & \\
\hline $\mathrm{Ge}(73)$ & 5.11 & $<0.1$ & & $<0.1$ & & $<0.1$ & \\
\hline As $(75)$ & 4.54 & 0.01 & & 7.2 & & 2.4 & \\
\hline $\mathrm{Se}(77)$ & 2.91 & $<0.1$ & & $<0.1$ & & $<0.1$ & \\
\hline $\mathrm{Sr} \quad(88)$ & 0.59 & 0.15 & & 0.30 & & 0.23 & \\
\hline Y $\quad(89)$ & 0.49 & 0.15 & & 0.18 & & 0.11 & \\
\hline $\mathrm{Zr}(90)$ & 0.76 & 0.45 & & 0.48 & & 0.32 & \\
\hline $\mathrm{Ag}(107)$ & 3.85 & $<1.5$ & & $<1.6$ & & $<1.1$ & \\
\hline Sn (119) & 2.20 & $<0.1$ & & 0.5 & & 2.2 & \\
\hline $\mathrm{Sb}(121)$ & 4.70 & $<0.05$ & & 0.37 & & 0.30 & \\
\hline $\mathrm{La}(139)$ & 0.67 & $<0.005$ & & $<0.005$ & & $<0.005$ & \\
\hline $\mathrm{Au}(197)$ & 1.81 & $<0.1$ & & $<0.1$ & & $<0.1$ & \\
\hline $\mathrm{Pb}(208)$ & 2.29 & $<0.01$ & & $<0.01$ & & $<0.01$ & \\
\hline $\mathrm{Bi} \quad(209)$ & 3.62 & $<0.01$ & & $<0.01$ & & $<0.01$ & \\
\hline${ }^{\dagger \dagger} \mathrm{Th}(232)$ & 0.54 & 0.00058 & $0.0003^{c)}$ & 0.00098 & $0.0051^{c)}$ & 0.00036 & $0.0076^{()}$ \\
\hline${ }^{\dagger \dagger} \mathrm{U} \quad(238)$ & 0.72 & 0.00012 & $0.0001^{\mathrm{c})}$ & 0.022 & $0.0042^{(*)}$ & 0.030 & $0.0090^{c)}$ \\
\hline
\end{tabular}

$\dagger \mathrm{VG}$ recommended, defined as unity for Mo; † 50 scans; a) combustion/IR absorption; b) vacuum fusion/pressure measurement; c) furnace AAS; d) ion exchange/ICP-AES; e) ion exchange/electrothermal vaporizationICP-AES

のことは,この“推奨 RSF”が高純度モリブデンの実際 分析には十分受当なものと判断してよく，かつ GD-MS が比較的マトリックス効果の小さい分析法であると言わ れていることも実証している，炭素や酸素については， ppm オーダーの定量分析が高度な技術を要し, 正確な 定量分析が極めて困難なこと, GD-MS においても例外 的にマトリックス効果を受けやすく, 使用した RSF 值 が適切であるかどうか疑問であり，大きな不一致もやむ
を得ないものと考えられる. ウランとトリウムについて は，掃引回数を 50 回に増すことによって $1 \mathrm{ppb}$ 以下の 定量も可能であり，スペクトルのプロフィルから定量下 限は両元素とも約 $100 \mathrm{ppt}$ と概算された。亜鉛, ガリウ ム, 銀についての分析結果には, なんらかの妨害を受け ている可能性がみられたのでこれらをまとめて Table 4 に示した.

亜鉛は, 同位体存在率の大きいものは 
Table 4 Analytical results of $\mathrm{Zn}, \mathrm{Ga}$ and $\mathrm{Ag}$ in molybdenum by using their several isotopes, ppm

\begin{tabular}{|c|c|c|c|c|c|c|c|}
\hline \multirow{2}{*}{ Isotope } & \multirow{2}{*}{$\underset{\%}{\text { Abundance }}$} & \multicolumn{5}{|c|}{ Sample } & \multirow{2}{*}{$\begin{array}{c}\text { Major } \\
\text { interference }\end{array}$} \\
\hline & & No. 1 & No. 2 & No. 3 & No. 4 & No. 5 & \\
\hline${ }^{64} \mathrm{Zn}$ & 48.6 & 0.05 & 1.9 & 2.3 & 0.79 & 0.95 & ${ }^{6+} \mathrm{Ni}^{+}$ \\
\hline${ }^{66} \mathrm{Zn}$ & 27.9 & 16.8 & 25.4 & 14.6 & 28.5 & 21.0 & ${ }^{92} \mathrm{Mo}^{+1)} \mathrm{Ar}^{2+}$ \\
\hline${ }^{68} \mathrm{Zn}$ & 18.8 & 29 & 43 & 34 & 48 & 36 & ${ }^{96} \mathrm{Mo}^{40} \mathrm{Ar}^{2+}$ \\
\hline${ }^{69} \mathrm{Ga}$ & 60.1 & 10.3 & 15.6 & 9.6 & 17.1 & 13.0 & ${ }^{98} \mathrm{Mo}^{40} \mathrm{Ar}^{2+}$ \\
\hline${ }^{71} \mathrm{Ga}$ & 39.9 & $<0.05$ & 0.35 & 0.11 & 0.14 & $<0.05$ & \\
\hline${ }^{107} \mathrm{Ag}$ & 51.84 & 1.5 & 1.6 & 1.1 & 1.7 & 1.3 & $\dagger$ \\
\hline${ }^{109} \mathrm{Ag}$ & 48.16 & 4.1 & 4.5 & 3.1 & 4.4 & 3.9 & $\dagger$ \\
\hline
\end{tabular}

$\uparrow$ Not identified

${ }^{64} \mathrm{Zn}(48.6 \%),{ }^{66} \mathrm{Zn}(27.9 \%)$, 及び ${ }^{68} \mathrm{Zn}(18.8 \%)$ であ り,このうち ${ }^{64} \mathrm{Zn}$ は ${ }^{64} \mathrm{Ni}(0.91 \%)$ と重複するため, ニッケルが多い試料中の微量严鉛の定量には使えない. 超高純度モリブデンを含む 5 試料について, 上記 3 同 位体を用いた結果では，いずれも ${ }^{66} \mathrm{Zn}$ 及び ${ }^{68} \mathrm{Zn}$ を用 いて得られた分析值が ${ }^{64} \mathrm{Zn}$ を用いて得られた分析值よ りもはるかに大きな值を示した。これは, Table 1 にま とめた妨害イオンの他に, ${ }^{92} \mathrm{Mo}^{40} \mathrm{Ar}^{2+},{ }^{96} \mathrm{MO}^{36} \mathrm{Ar}^{2+}$, ${ }^{96} \mathrm{Mo}^{40} \mathrm{Ar}^{2+},{ }^{100} \mathrm{Mo}^{36} \mathrm{Ar}^{2+}$ などのイオンが生成し,これ らがそれぞれ ${ }^{66} \mathrm{Zn}^{+},{ }^{68} \mathrm{Zn}^{+}$のスペクトルに重複するも のと考えられる. 同様にガリウムについては, ${ }^{69} \mathrm{Ga}^{+}(60.1 \%)$ が ${ }^{98} \mathrm{Mo}^{40} \mathrm{Ar}^{2+}$ の妨害を受けるため ${ }^{71} \mathrm{Ga}(39.9 \%)$ を用いなければならない. 銀について は, ${ }^{107} \mathrm{Ag}(51.84 \%)$ と ${ }^{109} \mathrm{Ag}(48.16 \%)$ のいずれを用い ても精製度の高い試料で，他の多くの元素に比べ，高い 分析值を示したこと，しかも ${ }^{68} \mathrm{Zn}$ や ${ }^{69} \mathrm{Ga}$ を用いたと きの亜鉛やガリウムと同じように，5試料についてほぼ 同等の分析値が得られたことなどの特徴がみられた．相 互に関連のない 5 試料について，このように銀の含有 量がそろうことは考え難く，この結果はなんらかの妨害 を含んだものと解釈した。

GD-MS はその簡易性, 迅速性から, 高純度金属の評 価や管理分析にふさわしい方法であった．現時点では RSF はVG Elemental 社推奨のものを使わざるを得な いが，それでも多くの元素について満足すべき結果を得 た．更に正確さの向上をめざすならば，標準試料又はそ れに代わるふさわしい試料を用い，RSFについて実験 的に検討を加え，その值に影響を与える要因を明らかに するとともに，新しい数值を提案する必要がある. 事
実，中村ら は銅とインジウムについての共同分析の報 告の中で, 新たに得た RSF と, この推奨 RSF との优 の違いを示し， RSF に対するマトリックスや放電セル の構造の影響を指摘している。適切な標準試料の作製を 待つと共に今後の課題となろう.

モリブデンやアルゴンに起因する妨害イオンの影響を 受ける元素に対しては, 妨害の程度やその元素の含有量 いかんでは, 極めて純度の高いモリブデンを分析し, 得 られた值をバックグラウンドとみなして補正することも 考えられる．しかし，この種の妨害は概して著しく，該 当する元素は分析の対象から除外される.

\section{$\left(\begin{array}{l}1991 \text { 年 } 11 \text { 月, 日本分析化学会 } \\ \text { 第 } 40 \text { 年会において一部発表 }\end{array}\right)$}

\section{文}

1) 河村梳夫: 分析化学, 37, 585 (1988).

2) O. Kujirai, M. Kohri, K. Yamada, H. Okochi: Anal. Sci., 6, 379 (1990).

3) L. F. Vassamillet: J. Anal. At. Spectrom., 4, 451 (1989).

4) 溝田隆之, 岩崎 廉：第 52 以分析化学討論会講 演要旨集 $(1991)$, p. 173.

5) 吉田有里, 田中正:隆, 西勝英雄: 日本分析化学会 第 39 年会講演要旨集 $(1990)$, p. 451 .

6）広瀬文雄, 伊藤真二, 大河内春乃：鉄鋼, 77, 598 (1991).

7) 中村 靖, 前田繁則, 永井 籌, 井上久成, 大瀧光 信, 山崎正行, 細井学, 新沃香代子, 佐山恭正, 川端智子: 分析化学: 40, T209 (1991).

8）岩崎 廉, 溝妇隆之: 日本分析化学会第 40 年会 講演要旨集 (1991), p. 311.

9) W. Vieth, J. C. Huneke: Spectrochim. Acta, 46B, 137 (1991). 


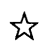

Determination of trace elements in high purity molybdenum by glow discharge mass spectrometry. Takayuki Mizota*, Tetsuya NaKamura ${ }^{* *}$ and Kiyoshi Inasaki ${ }^{*}$ ( ${ }^{*}$ Material Characterization Laboratory, Kanagawa High-technology Foundation, 3-2-1, Sakado, Takatsu-ku, Kawasaki-shi, Kanagawa 213; ${ }^{* *}$ Quality Assurance Department, Yokohama Metal Components Works, Toshiba Corporation, 8, Shin-sugita-cho, Isogo-ku, Yokohama-shi, Kanagawa 235)

The commercially available molybdenum metals, including a rod (Jhonson Matthey batch No. 31825) of high purity, were analyzed for their trace impurities by using a VG9000 glow discharge mass (GD-MS) spectrometer equipped with a highly sensitive glow discharge cell, the so-called "Mega cell", and a liq. $\mathrm{N}_{2}$ sample cooling system. The samples, mechanically shaped in rod form $(2.3 \mathrm{~mm} \times 2.3 \mathrm{~mm} \times 22 \mathrm{~mm}$ or $2.0 \sim 2.3 \mathrm{~mm}$ in diameter and $20 \mathrm{~mm}$ in length), were washed with aqua regia and deionized water, and then dried just before use. Preliminary sputtering in the glow discharge cell was required for surface cleaning of the sample: $30 \mathrm{~min}$ for the determination of most elements and $2 \mathrm{~h}$ for $\mathrm{C}, \mathrm{O}$ and $\mathrm{Cl}$ at $\mathrm{ppb}$ level. The discharge current was fixed to $3.0 \mathrm{~mA}$ and the discharge voltage was controlled at $1.00 \pm 0.05 \mathrm{kV}$ for the determination. Most of the elements at ppm level could be determined with a RSD of $3 \%$ or less. However, the determination of titanium was quite difficult because the overlap of doubly charged Mo ions on all isotopes of singly charged $\mathrm{Ti}$ ion is unavoidable under the adopted resolution of 4000 or a little higher. For the typical 16 elements which could be determined by ICP-AES, furnace AAS etc., the analytical values obtained by GD-MS were in good or reasonable agreement with those by other methods except for $\mathrm{C}, \mathrm{O}$ and $\mathrm{ppb} \sim$ ppt levels of $U$ and $T h$. These results suggest that the $V G$ recommended relative sensitivity factor used in this work is applicable to the analysis of high purity molybdenum metals.

(Received January 31, 1992)

\section{Keyword phrases}

glow discharge mass spectrometry; determination of impurities in high purity molybdenum; isobaric interference caused by Mo and Ar. 